\title{
The "Popular Press" Responds to Charles Darwin, The Origin of Species and His Other Works
}

\author{
Sidney Horenstein
}

Published online: 27 January 2009

(C) Springer Science + Business Media, LLC 2009

\section{Introduction}

I thought it would be interesting to examine the reaction to Charles Darwin's Origin of Species and his later works in the "popular press" of the United States. A search of books and articles for bibliographic citations was discouraging as were to some degree the extensive web pages devoted to Darwin and his works, for example, (http://darwin-online. org.uk and http://www.aboutdarwin.com). Although there are publications treating the scientific reaction to Darwin that was not my goal (for example, see: Darwinism. Comes to America by Ronald L. Numbers, Harvard University Press, 1998, 216 pages as well as similar publications related to the British reaction). As a result, I turned to various available sources on the web, such as www.google. com, cdl.library.cornell.edu/moa/ (Making of America), www.harpers.com, www.nytimes.com, www.bostonglobe. com, and databases that are available at some universities and libraries, such as www.jstor.com. A search in http:// firstsearch.oclc.org for the keyword "Charles Darwin" 1859-1882 yielded 1509 hits, most of which refer to his publications or publications in scientific journals that mention Darwin.

In general, I limited the time span between 1859, the year of the publication of the Origin of Species and Darwin's death in 1882. One aspect of these accounts is often the lack of authorship of the articles. I assume that many of them were written by the editors of the publications. The quotes were left as is; statements were

\section{S. Horenstein $(\bowtie)$}

American Museum of Natural History,

Central Park at 79th St.,

Manhattan, NY, USA

e-mail: horenst@amnh.org not verified for accuracy; and spelling was not corrected to modern usage. Instead of simply giving a list of citations, I thought it would be of interest to extract a few ideas presented from each article when appropriate. Doing so, however, did not do justice to the substance of many of the articles.

There are biases in the search for the articles. Keep in mind that there were thousands of newspapers and magazines: news, political, popular science, and religious during this time throughout the United States. Probably every substantial town had at least one such publication. However, the majority of them are not indexed and may or may not be available only in local libraries. So my point is that I am not sure whether what follows is entirely representative of the popular press at this time.

Originally, I thought I would group the articles by topic or attitude towards Darwin and his ideas, but, by and large, most of the longer articles contain more than one theme, making it difficult to do so; hence, the rationale for a chronological listing of the publications.

I searched the indexes for "Charles Darwin" because "Darwin" alone substantially increased the number of hits as a result of so many unrelated individuals or at least references to them sharing the Darwin surname. Not only that, but numerous articles mentioned Charles Darwin only in passing, perhaps once in an article, to reinforce some point that was being made but were not really about him or his theories. In addition, there were several works of fiction which included Darwin, but that genre was also not included. Books and monographs written about Darwinism and evolution and the religious reaction to his theories were not included because they were either technical or scientific and were not periodicals. The purpose was to discover what was covered and said about Darwin and his theories in the "popular press." 
One can anticipate the response from within various groups of society: conservative religious groups rejected Darwin and his Origin of the Species outright, while others stated that Darwin was a great naturalist and made important observations, but they could not accept his notions about the origin of man; some came on board immediately, while others quibbled about some of the details. Some scientists like Asa Gray wrote extensively about Darwin and evolution in the popular press. Still, there were a few surprises, one of which is the diminishing number of attacks against Darwin and Darwinism through this period. Not only that, regardless of the opinions expressed, most writers prefaced their remarks with the fact that they considered Charles Darwin to be a great naturalist and that he made important contributions to science. Often, religious liberals altered their interpretations of the scriptures to fit the new revelations in biological evolution. Most liberal churches accepted the antiquity of life and the paleontological record. Only a few small groups defended the recent appearance of life, attributing the fossil record to of Noah's Flood, a mindset that was not as widespread as it is today.

The following is a list of the publications mentioned in the articles below. Judging by the results of my search, only Darwin's books, for the most part, received press notices in the USA:

Journal of Researches into the Natural History and Geology of the Countries visited by H.M.S. Beagle, 1845

On the Origin of Species by Means of Natural Selection, 1859; 2nd edition, 1860, etc.

On the Various Contrivances by Which British and Foreign Orchids Are Fertilized, 1862; 2nd edition, 1877

The Variation of Plant and Animals under Domestication, 2 volumes, 1868; 2nd edition 1875

The Decent of Man, and Selection in Relation to Sex, 2 volumes, 1871; 2nd edition, 1882

The Expressions of the Emotions in Man and Animals, 1872

Insectivorous Plants, 1875

Different Forms of Flowers on Plants of the Same Species, 1877

The Power of the Movement of Plants, 1880

The Formation of Vegetable Mould, Through the Action of Worms, 1881.

\section{Publications}

New York Times January 4, 1860, page 6; a notice appeared indicating that "Mr. Lewes, it is said, is writing the opening article on Darwin's Origin of Species for the Cornhill Magazine." It can be assumed that the reading public was already familiar with Origin of Species and Mr.
Lewes and Cornhill Magazine, all of which are British, but this was the first notice I could find in the New York Times mentioning Darwin's Origin of Species.

The Sun, January 28, 1860, volume 46, no 62, page 2 mentions the Origin of Species and states that the volume is "A very learned, original and philosophical disquisition full of peculiar interest to the inquirer into the arena of nature."

American Publishers' Circular and Literary Gazette, February 18, 1860. volume 6, no. 7, page 81, contains an ad for the Origin of Species, cost \$1.25, stating that "five editions of this extraordinary work has been disposed of in England within a few weeks." It also contains a long quotation from the Boston Post— "This is an American reprint of a work destined to create no little excitement and conflict in the scientific world."

New York Times, March 28 1860, page 3, an extensive full-length article The Origin Of Species. In this discussion of Darwin's theories, the reviewer indicates that there are considerably more than 500,000 species of plants and animals on earth and that through geologic time, each "suite" of time contained at least as many. What accounts for the genesis of these million-fold incantations of life is the "mystery of mysteries." Darwin's most important "contribution ever made to philosophic science" that all lives that ever lived on this earth have descended from some one primordial form...." After reviewing the philosophical implications, the evidence Darwin accumulated, the comparison with current theories, one at first would think the author of this review leaned positively towards Darwin. "Shall we frankly declare that after the most deliberate consideration of Mr. Darwin's arguments, we remained unconvinced?"

San Francisco Bulletin, March 30, 1860, volume 9, no. 147, page 3, contains a notice of On the Origin of Species. "Many curious facts in natural history are here told, in support of the author's theory that species change, and are still slowly changing, by the preservation and accumulation of successive slight favorable variations." Other scientists, however, deny the mutability of species.

New York Observer and Chronicle, March 29, 1860, volume 38, no. 13, page 102; Darwin's New Theory adds that it is a "work of no little pretension and of some scientific interest...." The author confesses that he had in unanimous and often vehement opposition to him "all the most eminent paleontologists and all of the greatest geologists." By maintaining that life descended from some one primordial form, "he is forced to take positions which stagger the wildest credulity." "The objections, which the author cites against his own theory, and which he attempts to meet, are in our judgement insuperable, and some of them he admits for the present to be valid."

The North American Review, April, 1860, volume 90, no. 187, pages 474-507; a review of On the Origin of 
Species. "The author of this book endeavors to establish, though by a different theory and a somewhat different process of reasoning, the same conclusion, which was arrived at by the French naturalist, Lamarck, and by the English author of the Vestiges of Creation, namely that all the species, genera, orders, and classes of animal and vegetable life are essentially of one blood and lineage, having been developed out of one another without the intervention anywhere of any act of creative power...."

New Englander and Yale Review, May, 1860, volume 18, no. 70, pages 516-519; a review of Darwin's On the Origin of Species, 1860. "We do not question that it was nature's design to provide for many varieties by culture, and that many of the so-considered species may have originated from an original pair. But there is a limit beyond which analogy, pliable as it is, will not carry us....The naturalists will have a pretty fight of it among themselves...."

The Atlantic Monthly, July, 1860, volume 6, no. 33, pages 109-116, contains an early review, Darwin on the Origin of Species, by Asa Gray. "Novelties are enticing to most people; to us they are simply annoying. We cling to a long-accepted theory, just as we cling to an old suit of clothes. A new theory like a new pair of breeches...is sure to have hardfitting places.... New notions and new styles worry us, till we get well used to them, which is only by slow degrees." Asa Gray continues by listing the "admitted facts" that suggests the hypotheses of derivation.

Living Age, July 7, 1860, volume 66, no. 840. pages 326, contains a reprint from Edinburgh Review. This article lists ten scientific articles and books. "In the works above cited the question of the origin, succession, and extinction of species is more or less treated of, but most fully and systematically by the accomplished naturalist, which heads the list. Mr. Charles Darwin, has long been favorably known, not merely to the Zoological but to the Literary World, by the charming style, in which his original observations on a variety of natural phenomena are recorded...."

New York Times, August 6, 1860, page 4; an editorial The Advance of Science reported that the British Association of the Advancement of Science "declined to discuss the merits of Mr. Darwin's new theory of the origin of species" causing considerable comment in England despite the fact that it had been known for almost a year and had "provoked discussion, both popular and scientific, in all parts of the world." Because the theory was "novel, in conflict with established beliefs and seemed to offer solutions for a thousand difficulties, which beset theories currently received" its merits should have been discussed. Instead, the British Association, to the disappointment of everybody, adjourned without passing any judgment. In fact, it provided an "opportunity for a Bishop of the English Church to denounce its heretical tendencies." The editorial was written because the American Association was meeting at Newport and "seemed equally disposed to give the propositions of Mr. Darwin a wide berth." No papers were presented related to the Origin of the Species. However, "Agassiz, to whose doctrines that of Darwin is in open antagonism, is present at Newport..." While in England, many of the naturalists and paleontologists are dependent upon "a Government which would certainly look with displeasure upon the indorsers of a theory...that might threaten war upon the foundation of the established religion. Here no such establishment exists, and no such fear need to be entertained." Then, later (New York Times, August 25, 1860, page 1) in a long article about the progress and prospects of science in America based on the meetings at Newport, the author indicated that there were defenders of Darwin "had the question been allowed to come up."

The Atlantic Monthly, October 1860, volume 6, no. 36, pages 406-425, contains article Darwin and His Reviewers. "Two hypotheses divide the scientific world, very unequally, upon the origin of the existing diversity of the plants and animals, which surround us. One assumes that the actual kinds are primordial; the other that they are derivative. One, that all kinds originated supernaturally and directly as such and have continued unchanged in the order of Nature; the other, that the present kinds appeared in some sort of genealogical connection with the other and earlier kinds and that they became what they now are in the course of time and in the order of Nature."

Little's Living Age, June 29, 1861, number 891, page 782; a reprint of a song from Blackwood's Magazine, The Origin of Species: A New Song, with supplemental quotes from the Origin of Species.

The Albion; A Journal, of News, Politics and Literature, June 14,1862 , volume 40 . no. 24, page 279; a literary look at Darwin dumping a bucket of his studied creatures, his ancestors, over the side of The Beagle; hence, the title of the article Immortals By Accident.

The Methodist Quarterly Review, October 1861, volume 13, pages 605-627; "The author of this ingenious book," On the Origin of Species, "is a grandson of Dr. Darwin, the celebrated author of The Botanic Gardener, The Love of Plants,...and other poetical and scientific works, is full of fanciful theories and rather suspicious theology. Whatever, therefore, may be his speculative eccentricities, we may fairly presume that he has come honestly to them."

The Biblical Repertory and Princeton Review, July 1862, volume 34 , no. 3, pages 435-464; a review of the literature about the diversity of species in the human race. In an article Examination of some Reasonings against the Unity of Mankind, the author states that Dr. Morton and Professor. Agassiz "find such differences between man and man, that the different races or groups never could have descended 
from a single pair; while Darwin finds as little difference between man and animals, that he believes them all to be descended from at most only four or five."

The New England Farmer; a Monthly Journal, May 1864, volume 16, no. 5, page 132 contains an article Respect the Earth-worm. "Farmers are generally aware that the earth-worm luxuriates in a rich soil, but they are not disposed to give him any credit for contributing to its fertility. But the Creator is wiser than they, and He gave the farmer efficient helpers underground, who do Him service, without pay in money or even in Thanks....Mr. Charles Darwin has shown that in thirteen years, a field of pasture was covered to a depth of three inches and a half of mold discharged from their intestines."

The Atlantic Monthly, October, 1866, volume 18, no 108, pages 415-425; Charles J. Sprague in this article, The Darwinian Theory, begins his review by offering a "great interest has been awakened, of late, by the promulgation of a new Theory of Creation; and non-scientific readers have met with numerous controversial articles in journals, magazines, and newspapers of the day....In spite of the sneers and sarcasms, which have been launched by writers, lecturers and preachers...few really and thoroughly comprehend Mr. Darwin's idea...." The author proceeds with a review of the relationship of scriptures and the natural world, some of the resultant theories, followed by a description of the Darwinian Theory, which "is erected on the primary foundation of a natural law acting through all time...."

The Galaxy, July, 1868, volume 6, no. 1, pages 135-138, contains a review of The Variation of Animals and Plants under Domestication, which is a continuation of the inquiry opened by Mr. Darwin in his volume On the Origin of Species, in 1859. The current review, instead of analyzing the content of the new work, points "out their relation to the content of the original book and to Mr. Darwin's general theory."

Ohio Farmer, August 1, 1868, volume 17, no. 31, pages 482, 483; we have decided to give the readers of the Ohio Farmer a taste or at least a synopsis of the subject of Darwin's Variations of Animals and Plants Under Domestication, "but we find it impossible; to be fairly understood the work must be studied at length. As a result we have inserted a very candid review of the work from The North American Review. The present book harrows and refreshes, as it were, the whole field of, which it treats. It is doubtless provisional but none the less serviceable for that, and we cordially recommend it to the student."

American Phrenological Journal, October, 1868, volume 48 , no. 4 , pages 121,123 , includes a portrait and a physiognomist description of Darwin's character, intellect, ambition, and facility as an inquirer. "Mr. Darwin's reputation is, of course, very extended; but his influence is probably strongest in Germany, where he has received many honors from the most influential scientific societies."

Putnam's Magazine, October 2, 1868, volume 2, no. 10, pages 505, 506; readers of Darwin's Origin of Species “will remember that the work only professed to be a general statement of theory, which needed a great deal of elaboration and illustration. The present work, The Variation of Animals and Plants under Domestication, is the first installment of the complete work. It has no practical intent whatsoever, and yet it is a book, which every intelligent farmer would do well to read; for if it does not furnish him with practical suggestions, it can make him a more reverent worker in view of the great laws in which his humblest offices take root and grow."

The Universalist Quarterly and General Review; October 5, 1868, pages 493-497, contains a review of Variations of Animals and Plants under Domestication. "Whatever may be thought of the author's speculations, there can be but one opinion regarding the patience, diligence, accuracy and extent of his observations. The eager curiosity felt in regard to the questions involved in the discussions, may be judged by the fact that the first English edition was exhausted in a single week. The reader speedily discovers that the author is thoroughly committed to his theory of development, and sees everything, and shapes every fact, with an eye single to that."

The Manufacturer and Builder, November 1870, 1870, volume 2, no. 11, page 339; the principle, which is the base of the Darwinian Theory, was (rather obscurely) announced by R. Wallace in 1855. "It is gratifying to notice how free are these two pioneers from a petty jealously of one another's fame." In a preface to the Origin of Species, Mr. Wallace says "I have felt all my life, and I still feel, the most sincere satisfaction that Dr. Darwin had been at work long before me, and that it was not left for me to attempt to write the Origin of Species."

New York Times, March 13, 1871, page 4; "In reviewing this book of Mr. Darwin's The Descent of Man, and Selection in Relation To Sex, we shall endeavor to give an impartial outline of his arguments, without discussing at present the opinions set forth, still less desiring it to be understood that we concur in Mr. Darwin's conclusions. Our aim now is to make the reader acquainted with the general line by Mr. Darwin."

The Independent, March 16, 1871, volume 23, no. 1163, page 6, mentions the republication of Mr. Darwin's Journal of Researches, which details his voyage on the Beagle between the years 1831 and 1836. "Those who have taken an interest in the later writings of this great naturalist will find new interest in tracing the date and origin of that thought..., which have affected the world of thinkers."

The Albion, A Journal of News, Politics and Literature, April 1, 1871, volume 49, no. 13, page 201; a brief review 
of The Descent of Man, and Selection in Relation to Sex. "In the whole history of scientific research there is scarcely a case so remarkable of a system of doctrines, at first generally condemned as false and absurd, coming into general acceptance in the scientific world in a single decade...."

Chicago Tribune, April 9, 1871, page 2; "The publication of a fresh book by Mr. Charles Darwin, on the Descent of Man, naturally leads one to serious reflections concerning his ancestry. One would think that the development of man from a sponge, or a spore, or a polyp, should be styled as ascent rather than descent. But Mr. Darwin evidently prefers, as an Englishman, to consider the quest as one of pedigree rather than evolution."

Zion's Herald, April 13, 1871, volume 48, no. 15, page 173; in this brief review of The Descent of Man, and Selection in Reference to Sex, it is stated that the author, Charles Darwin, "displays the same wealth of learning and ingenuity... which has placed him in the foremost ranks of philosophic naturalists. Nevertheless, some of his conclusions appear to us not proven, and others we believe altogether erroneous."

Christian Advocate, May 11, 1871, volume 46, no. 19, page 146; contains a brief note: "A really witty caricature has just appeared in the London Shop windows, that of a large and venerable orang-outang with Professor Darwin's face...labeled 'A Contribution to (un-) Natural History."'

The Eclectic Magazine of Foreign Literature, June 13, 1871, volume 13, no. 6, page 757; an article, Professor Charles Darwin, which is a brief biography and description of his major publications up to the current date.

Harper's New Monthly Magazine, July, 1871, volume 43, no. 254, pages 305-307; "Few scientific works have excited more attention than the one just published by Mr. Charles Darwin, upon The Descent of Man....This treatise has been discussed from almost every point of view, and it is almost impossible to take up a periodical at all interested in such subject without finding one or more notices of the book. Among the best written of these criticisms may be cited one published in the late number of The Academy, from the pen of Mr. Alfred R. Wallace... and although known to agree with Mr. Darwin in some of his views, yet entirely opposed to him in others."

Overland Monthly and Out West Magazine, July, 1871, volume 7 , no. 1 , pages 98,99 , contains a review of the Descent of Man in which the author states that "aside from the question whether the Darwin hypothesis is true or false, the best natural history of modern times is furnished in, The Descent of Man, and with the preceding works which are necessary linked with the later one, and really constitute one treatise on natural history. When we arrive at the last of Darwin's facts, we have the alternative of attempting to cross the wide and almost bottomless gulf on the farther side of which the Darwinian conclusion is reached or go back and note the strength and objections to Darwin's conclusions" as others "have set forth."

North American Review, July, 1871, volume 113, no. 232, pages 63-104; an article The Genesis of Species by Chauncey Wright. It would be appropriate to think that after the Origin of Species was published there would be shortlived interest in the ideas presented in the book after having been "condemned by cautious and conservative thinkers to the limbo of insoluble problems or to the realm of religious mystery." Every year, however, has increased the interest attested to by the publication of the flowing books which are reviewed here: Contributions to the Theory of Natural Selection by Alfred Russel Wallace, 1870; On the Genesis of Species by St. George Mivart, 1871; The Descent of Man, and Selection in Relation to Sex by Charles Darwin, 1871; and On the Origin of Species by Means of Natural Selection by Charles Darwin, 1871.

Scribner's Monthly, September, 1871, volume 2, no. 5, pages 556, 557; contains a review of The Genesis of Species by Mr. St. George Mivart and compares it with Darwin's hypotheses. "Under pangenesis Mr. Mivart brings together an array of strong objections against Mr. Darwin's far-fetched provisional hypotheses."

The Independent, October 19, 1871, volume 23, no. 1194, page 6; "Everybody is aware of what Darwinism is and it will not be necessary to review his work, Descent of Man, at length till we have the second volume. Our readers know, or ought to know, that the day of ridiculing the Theory of Development has quite passed by."

The Living Age, February 17, 1872, volume 172, no. 144, pages 385-448; an article reprinted from the Westminster Review on The Geographical Distribution of Animals and Plants, Geologically Considered. "The subject we have chosen for treatment in the present article is one of the deepest interest to naturalist. The facts of which it treats have only fallen into their harmonious arrangement since the publication of the 'Origin of Species.' Darwin may well claim that only from his point of view can the subject of the Geographical Distribution of animals and plants be scientifically treated."

North American Review, July, 1872, volume 115, no. 236, pages 1-31, contains an article by Chauncey Wright, Evolution by Natural Selection. Herein is a discussion of the Origin of Species, etc. by Charles Darwin, 6th edition; Evolution and its Consequences, a reply to Professor Huxley by St. George Mivart; published in Contemporary Review, January 1872; and Specific Genesis by St. George Mivart, a communication in the North American Review, April, 1872. The question of how animals and plants came to have structures and habits that characterize them as distinct species is now a direct question for scientific investigation and that this effect was by some natural 
process and was not by a formless creative first. This natural process connects the living form of the present with very different form of the past- "descent with modification." It is highly desirable that discussions of this concept should be free as possible from mere personalities and continues "through the manners and method of procedure" that is the basis of modern science.

New York Times, February 7, 1873, page 2; in a review of The Expressions of the Emotions in Man and Animals, by Charles Darwin, the author of the review asks "how does man recognize in his fellowman the presence of an inner spirit, and more or less follow its working and trace its various moods?" and other related questions. "How in short does man externally make manifest the ebb and flow, the rising and falling, of the ever-changing tides of feeling which regulate his actions and control his course? This is the chief problem to which Mr. Darwin devotes himself in his last work..." In conclusion, the author(s) of the article decide(s) that "Mr. Darwin's work appears to us to fall short of its intended mark by really explaining very little, while it seems to explain a great deal."

The Catholic World, August 1873, volume 17, no. 101, pages 641-655; More about Darwinism is about The Expressions of the Emotions in Man and Animals. "Man is a monkey perfectly developed." The developing process is the result of habit transmitted, imitation, and practice. "The reasoning of the entire volume may be summed up in the following syllogism: the expressions of the emotions in man and animals are, for the most part, similar, nay, alike. Now this could not be so, did man not descend from the animal; therefore, man is the offspring of the brute. The article concludes that "there is, we admit a germ of truth in the theory of evolution. The mistake is in applying it without limit. Scientists should not forget that reason is the handmaid of revelation."

The Popular Science Monthly, August, 1874, volume 5, pages 475-480, contains the article An Estimate of Darwin, Appended is a full List of Mr. Darwin's Works by Asa Gray, comparing Charles Darwin with another British naturalist, Robert Brown. "The vast amount of such work" Darwin "has already accomplished might overtax the powers of the strongest. That it could have been done at all under constant infirm health is most wonderful."

Chicago Daily Tribune, August 29, 1874, page 10; a brief biography of Charles Darwin

Friend's Intelligencer, September 12, 1874, volume 31, no. 29, page 463; "Sir Charles Darwin, by close study of the habits of pigeons, has worked out the frame of his theory of the progress of species from lower to higher forms."

New Englander and Yale Review, October, 1874, volume 33, no. 129, pages 741-770; this review, Mr. Darwin and the Theory of Natural Selection, by Lyell T. Adams, includes a history of how the doctrine was formulated starting when the British and French Governments jointly agreed to survey the coast of South America. The editors of the journal state that "the excellent description and just criticism of the Darwinian Theory, which this article contains, give to it a special value. If, however, the author is to be understood as implying, in two or three places, a necessary incompatibility between the Theory of Darwin and the Doctrines of Christian Theism, his position in this particular is open to question."

Medical and Surgical Reporter, February 13, 1875, volume 32, no. 7, page 135; an article Transmission of Descent, the theory of evolution, "including, of course, the evolutional psychology which has been rapidly gaining favor of late, is based on the laws of heredity transmission. The investigation of Prosper Lucas necessarily preceded the generalizations of Charles Darwin. The latter stand or fall with the former."

The Independent, August 26, 1875, volume. 27, no. 1395 , page 10; mentions the publication of "Insectivorous Plants."

Chicago Daily Tribune, September 18, 1875, page 3; a review of "Insectivorous Plants....The reader will gain an... impressive conception of the years of slow, cautious and untiring study by which the naturalist arrives at the true history of the organic and inorganic world."

New York Evangelist, December 23, 1875, volume 46, no 51, page 7; an article titled the Earth-worm. How useful is the earthworm? "The goodness of God is so wonderfully displayed in the usefulness of this apparently worthless reptile." This is followed by a lengthy quote from Charles Darwin's work on the importance of earthworms.

Essays and Reviews Pertaining to Darwinism by Asa Gray, 1876, New York: Appleton and Company, 396 pages. "These papers are now collected at the request of friends and correspondents, who think that they may be useful.... Most of the articles were written as occasion called for them within the past sixteen years and contributed to various periodicals....The first appeared between sixteen and seventeen years ago, immediately after publication of Darwin's Origin of Species...which it was then foreseen, was to initiate a revolution in general scientific opinion."

Chicago Daily Tribune, May 13, 1876, page 10, a brief note mentioning Darwin's new book about experiments in the fertilization of flowers.

Scientific American, June 17, 1876, volume 34, no. 25, page 384; a review of Darwin's theory of pangenesis as described in his second edition of Animals and Plants under Domestication.

Chicago Daily Tribune, June 5, 1876, page 7; mentions a new edition of The Variation of Animals and Plants under Domestication.

Scribner's Monthly, October, 1876, volume 12, no. 6, pages 907-909; reviews The Variation of Animals and 
Plants Under Domestication. "In the introduction of his Origin of Species published seven years ago, Mr. Darwin says that it 'must necessarily be imperfect.... can give only the general conclusion at which I arrived, with a few facts in illustration, but which I hope in most cases will suffice...." But Darwin felt the "necessity of hereafter publishing in detail all the facts, with references, on which my conclusions have been grounded, and I hope in a future work to do this...." The publication now being reviewed was first published in 1868 and this second revised edition, is "enriched by observations...is the fulfillment of the hope then expressed." After a positive evaluation, the reviewer concludes that "we feel assured that we will learn not that the world is without a personal God; but only that this God has been working throughout the past ages of eternity and is still working."

Chicago Daily Tribune, February 10, 1877, page 8, reprint of a letter by Darwin explaining why hollies will have few berries: bees the transporters of pollen were rare in the spring.

Christian Union, February 28, 1877, volume 15, no. 9, pages 182, 183; an article, The Entrenchments of Skepticism by Rev. I.T. Townsend, in which he states that evolution theories are not, as many suppose, altogether modern; they can be traced back to the fifth century B.C. "Atheists are no longer rarities;...every pulpit is ringing with proofs that God and not evolution is the cause of creation...."

The Independent, March 22, 1877, volume 29, no. 1477, page 26; Sir John Lubbock who spent three years studying ants, lives on a farm adjoining Darwin's who, no doubt, communicates with "that great man," declared at a lecture that though the "ape ranks next [to] man in form, the ant ranks next [to] him in intellect." The article is a reprint of Wonderful Things About Ants by M.D. Conway, from the Cincinnati Commercial.

Prairie Farmer, April 21, 1877, volume 48, no. 16, page 122; an article on the conclusion reached by Darwin that bees and various other insects "appear to search for nectar and pollen by instinct."

Scientific American, April 21, 1877, volume 36, no. 16, page 240; "It is impossible to finish the perusal of any of Charles Darwin's works without a general feeling of admiration...." In his recent book on the effects of crossand self-fertilization of plants, the first and most important conclusion is that "cross-fertilization is generally beneficial and self-fertilization injurious." This is followed by a discussion of whether marriage between first cousins is injurious.

New York Times, April 30, 1877, page 3; a notice of The Various Contrivances by which Orchids are Fertilized by Insects, 2nd edition. This work first published in 1862 "has received a careful overhauling by the distinguished author for the second edition." The note contains brief interesting facts from each chapter.

The Universalist Quarterly and General Review, July 14, 1877, pages 385, 386; "Mr. Herbert Spencer is performing for the doctrine of Evolution the service in philosophy that Charles Darwin is performing for it in the domain of natural history."

Chicago Daily Tribune, November 17, 1877, page 9; "The University of Cambridge purposes to confer the degree of LL.D upon Mr. Charles Darwin."

Christian Advocate, December 13, 1877, volume 52, no. 50, page 794; a notice of a new work by Darwin, Different Forms of Flowers on Plants of the Same Species with an introduction by Asa Gray.

The Catholic World; A Monthly Magazine of General Literature and Science, January, 1878, volume 26, no. 154, pages 496-511, contains an article The Descent of Man. "Mr. Charles Darwin, proposes to himself to show that man is nothing more than a modified beast, and that his remote ancestors are to be found among the tribes of brutes. A paradox of this kind, in a work of fiction such as Ovid's Metamorphoses, would not offend an intelligent reader; but in a work which professes to be serious and scientific it is extremely offensive, for it amounts to a deliberate insult to all humanity in general and to every human being in particular. Mr. Darwin's work violates the dignity of human nature, blots out of our souls the image and likeness of our Creator, and totally perverts the notions most cherished by civil and Christian society."

Zion Herald, January 17, 1878, volume 55 no. 3, page 18 , notes that "On the 17 th day of last November the degree of Doctor of Laws was conferred upon Mr. Charles Darwin in the Cambridge (England) Senate house. The undergraduates had an imitation monkey dressed up in academicals suspended on a string, and swung across the building."

The Independent, March 7, 1878, volume 30, no. 1527, page 7; sons Francis and George Darwin "have already contributed many valuable additions to our scientific knowledge." Francis read a highly interesting paper before a meeting of the Linnaean Society of London on an experiment with carnivorous plants. Result: those plants that were fed periodically by the Darwins were heavier and produced heavier seeds and higher, more numerous stems than the plants left on their own.

Friends Intelligencer, April 20, 1878, volume 35, no. 9, page 142; reprint of the article in The Independent for March 7, 1878 above.

New York Times, April 30, 1877, page 3; a review of The Various Contrivances By Which Orchids Are Fertilized By Insects, 2nd edition.

The North American Review, May/June, 1878, volume 126, no. 257, page 474; "Is Man a Depraved Animal" is the 
title on an article by O. B. Frothingham. Although it is not about Darwin but, in part, as the title suggests, about the nature of man, I included this article because it shows, as so many others, that Darwin's ideas are pervasive and used in passing in many articles, although not necessarily correctly. Writing about the nature of Adam, derived from an interpretation of the Bible, one cited author describes him as "having no character; he is without moral conscience, desire, or will; the knowledge of good and evil he has not attained. He is innocent and undeveloped; vacant of ideas; an embryo; a possibility. He corresponds better with the description of first man given by Charles Darwin." This is the only place in the article where Darwin is mentioned directly or indirectly.

Chicago Daily Tribune, June 8, 1878, page 9; a brief review of Transformations (or Metamorphoses) of Insects... by Peter Duncan, 3rd edition, "an admirable work which has been standard among entomologists" includes a compilation from the works of Charles Darwin and others.

The Friend; A Religious and Literary Journal, August 17, 1878, volume 52, no.1, page 5; part of an extensive article, Present Conflict of Science with the Christian Religion by Herbert W. Morris in which he states "No theory could easily be imagined than more fundamentally adverse to the Christianity than that of development as presented by Charles Darwin...."

Chicago Daily Tribune, November 3, 1878, page 4; in the article The Evolution of Rascality, it is mentioned that Darwin's account of the Descent of Man gives "genesis the go-by." As might be expected, he has been "met with violent resistance among learned men of the time...but...it soon found able and eloquent advocates." What follows is a description of rascality (thievery and murder, really) among well-known businessmen, politicians, and others.

Southern Planter and Farmer, January, 1879, volume. 40, no. 1, pages 29, 30; a reprint of an article in Gardner's Monthly by Peter Henderson about a test in New Jersey to verify the Darwin's conclusion "with respect to the benefit derived by carnivorous plants from the insects they destroy." A group of carnivorous plants were fed and an equal group was not. After three months, the plants were examined, and there was no difference between the groups. This test corroborating the result found by Mr. Darwin failed.

Scientific American, January 11, 1879, volume 40, no. 2, page 23; contains a somewhat abbreviated version from the Southern Planter and Farmer above.

New-York Evangelist, May 1, 1879, volume 50, no. 18, page 1 ; contains a dialogue in the form of a poem between a well-known minister, Dr. G.B.C., and Charles Darwin on The Origin of Man.

The American Catholic Quarterly Review, A Magazine of General Literature and Science, July, 1880, volume 5, no. 19, pages 570, 571, reviews Erasmus Darwin by Ernst Krause with a Preliminary Notice by Charles Darwin, 1880. The preliminary notice, the longest part of the book, is a history of Erasmus Darwin's life. Dr. Krause's brief essay is entirely concerned with the analysis of the elder Darwin's works "and the vindication of his claim to be the true founder, in great part, at least, of the system of evolution through natural selection of which his grandson is the exponent in our day."

Chicago Daily Tribune, January 31, 1880, page 9, contains a review of the Life of Erasmus Darwin by Ernst Krause with a Preliminary Notice by Charles Darwin, in which is noted that almost every single work of Charles Darwin "may be paralleled by at least a chapter in the works of his ancestor... are to be found already discussed in the writings of the elder Darwin."

The Manufacturer and Builder, March, 1880, volume 12, no. 3, page 63; "Most naturalists, writes Mr. Charles Darwin in Nature, appear to believe that every instinct was at first consciously performed; but this seems to me an erroneous conclusion in many cases, though true in others." Instinct is the result of inherited actions unconsciously performed.

The Journal of Speculative Philosophy, April, 1881, volume 15 , no. 2, page 206, 207, contains a letter from Charles Darwin about infant education.

Littell's Living Age, April 16, 1881, volume 149, no. 1922, page 192; a letter written by Charles Darwin originally published in Nature and reprinted here on the movement of plants.

New York Times, April 30, 1881, page 2, contains a letter written by Darwin on vivisection in which he writes that experiments on living animals are necessary to the progress of physiological study.

Christian Advocate, July 14, 1881, page 14, same as above in New York Times, April 30, 1881 but here reprinted from the Medical Times Gazette.

The Independent, July 21, 1881, volume 33, no. 1703, page 12, contains a review of Darwin's book, The Power of the Movement of Plants.

Scientific American, September 3, 1881, volume 45, no. 10 , page 151 , contains an article on inheritance by Charles Darwin.

The Washington Post, September 9, 1881, page 3, contains a letter by Darwin about babies that casts light on what babies know.

Chicago Daily Tribune, November 14, 1881, page 7; article about what people owe to the earthworm based on Darwin's book on worms, The Formation of Vegetable Mould, Through the Action of Worms.

Chicago Daily Tribune, January 14, 1882, page 9, a review of Darwin's volume on worms.

The Friend; A Religious and Literary Journal, January 28,1882 , volume 55 , no 25 , page 199 ; a reprint of an 
article in the Christian Advocate by J.R. Loomis on Darwin's study of earthworms.

Catholic World, February, 1882, volume 34, no. 203, pages 683-692, contains an article, Evolution, by W.R. Thompson. The object of writing this article is to present as plainly and as simply as possible the "main arguments or more accurately, line of arguments, on both sides of the question, which is a short consideration of the alleged contradiction which evolution presents to religion." When the theory of creation by evolution "was first advanced it was met by a storm of dogmatic abuse. It was ridiculed, pooh-poohed, abused, called the 'dirt theory,' and scarcely given a hearing. Now the tables are completely turned, so that the man who today opposes it is treated very much the same way as if he denied the revolution of the earth around the sun."

Californian, February 5, 1882, volume 5, no. 26, page 190-192, a book review of Darwin's volume on worms.

N.B. Although Charles Darwin died on Wednesday, April 19th, 1882 at 4 PM, his funeral took place a week later on April 26 in Westminster Abbey. His coffin was covered with wreaths of flowers, and the pall-bearers consisted of many notable persons including Prof. Huxley and Alfred Russel Wallace. His body was buried in close proximity to Sir Isaac Newton with whom he was compared so as to equate Darwin with greatness.

Notice of Darwin's death and funeral was reported in many newspapers and magazines. Some religious commentators took the opportunity to address Darwin's views on religion and his theory on the origin of man.

New York Times, April 25, 1882, page 1; "Cannon Liddon preaching at St. Paul's Cathedral...referred to the theories as not necessarily hostile to fundamental truths of religion. Darwin possessed charity which was the essence of the spirit of Christianity."

The Washington Post, April 25, 1882, page 1, describes the evening service prior to funeral.

The Washington Post, April 27, 1882, page 1, describes the funeral and lists some of the participants.

Christian Union, April 27, 1882, volume 25, no. 17, pages 390, 391; a notice of his death and a review of his work in regards to Christianity. "He set an example which was more Christian than the uncandid zeal of some of his Christian antagonists. As a consequence, his service to science, and so to humanity, will be remembered long after the heat of the controversy has passed away."

The Independent, April 27, volume 34, no. 1743, page 16 , reports on Darwin's death that "we wish we needed to no more than describe" his achievements; but unfortunately that is not the case. "The attitude of the Church toward him, more hostile than suspicious even, is an occasion for deep mortification."

Scientific American, April 29, 1882, volume 46, no. 17, page 256 , contains a notice of his death, his family tree, schooling, voyages, and many of his publications. "His most eminent characteristic, however, has been an unswerving loyalty to truth as obtained by exact observation and unprejudicial judgement, regardless of ridicule or misrepresentation."

The Friend; A Religious and Literary Journal, April 29, 1882 , volume 55 , no 38 , page 304 , contains a notice of Darwin's death.

The Dial; a Semimonthly Journal of Literary Criticism, Discussion and Information, May 3, 1882, volume 3, no. 25 , pages $2-4$, reviews Darwin's work.

The Critic, May 6, 1882, volume 35, page 130, a positive review of Darwin's "Darwinism."

Literary World, May 6, 1882, pages 145, 146; a memorial to Charles Darwin by Asa Gray, written on the day of his funeral, expanded in the American Journal of Science, December 24, 1882, volume 24, no. 144, pages 453-463, American Arts and Sciences Proceedings, Boston, June 17, 1881-June 1882, pages 449-458, and in various forms in several other magazines in the months after his funeral.

New York Times, May 7, 1882, page 3, describes his last days and that he was not honored by the country enough.

New York Times, May 16, 1882, page 2, describes in a lengthy article the countryside and some of the neighbors around Downe [Down], the home of Darwin.

The Unitarian Review and Religious Magazine, May 17, 1882 , volume 5 , no. 5 , pages $452-457$, is a review of his works and the controversies surrounding them. "We have learned that no nearer approach to the truth of nature can disturb pure religion and that the most profound investigation into her secrets will result in a grander revelation of Deity, and afford reasons for a more stable faith. This step we owe to Darwin more than to any other person."

Christian Union, May 25, 1882, volume 25, no. 21, page 486 , notes that opinion is not unanimous about the universal law of evolution with which his name will always be identified, but the religious objection to it is generally and perceptively allayed."

The Independent, May 25, 1882, volume. 34, no. 1747, page 29, reprints part of an article published in Nature, April 6, 1881, on the dispersal of fresh-water bivalves, "probably the last article published during his life-time...."

New York Times, May 26, 1882, page 4, mentions that a project has been started for some appropriate monument in the memory of Charles Darwin in Westminster Abbey as well as a scholarship in his name to foster scientific work.

Harper's New Monthly Magazine, June, 1882, volume 65 , no. 385, pages 153, 154; the naturalist White of Selbourne in the 1770s wrote that "Earth-worms though in appearance a small and despicable link in the chain of nature, yet, if lost, would make a lamentable chasm." Charles Darwin knew of White's observations and in 1837, 
in one of his earliest contributions to science, read a paper before the Geological Society of London on The Formation of Mould. Darwin continued his observations and in 1881 he published The Formation of Vegetable Mould Through the Action of Worms.

Atlantic Monthly, June, 1882, volume 49, no. 296, pages 835-852, contains an article Charles Darwin by John Fiske. Now that Charles Darwin's funeral has taken place "it seems a fitting occasion to utter a few words of tribute to the memory of the beautiful and glorious life that has just passed away from us.... When the extent of his work is properly estimated, it is not too much to say that among all the great leaders of human thought that have ever lived there are not half a dozen who have achieved as much as he."

The Dial; a Semimonthly Journal of Literary Criticism, Discussion and Information, August 3, 1882, volume 3, no. 28, page 77, reviews Sir John Lubbock's "Ants, Bees and Wasps." He was a friend and neighbor of Charles Darwin who asks "whether or not his associations with the great scientist influenced his studies...."

The Independent, August 10, 1882, volume 34, no. 1758, page 4, prints a poem, Charles Darwin, by the late Fanny Parnell.

Medical and Surgical Reporter, August 12, 1882, volume 47 , no. 7 , page 179 , reports that $\$ 12,000$ in subscriptions and been received or promised for a marble statue of Charles Darwin to be installed in the large hall of the Natural History Museum, South Kensington, England.

New York Times, August 28, 1882, page 3, a review of an article about Darwin in the Church Quarterly Review, July 1882 , states that it "is the most appreciative paper from a conservative quarter on the teachings of Darwin that has yet been written...and argues in favor of the Darwinian Theory with religious belief."

Christian Union, September 7, 1882, volume 26, no. 10, page 192, an article by The Rev. Charles F. Deems, Darwin in Westminster; is a response to those who objected to Darwin's internment in Westminster Abbey. Intolerance toward both Christianity and Darwin "should cease."

Littell's Living Age, September 16, 1882, volume 154, no. 1994, pages 643-653, contains an extensive review of Darwin's publications. As far as religion goes, the author states that "The fundamental doctrine of the theist is left precisely as it was. The belief in the Great Creator of the universe is, as we have seen, confessed by the author of these documents."
Christian Advocate, October 12, 1882, volume 57, no. 41, page 1, reprints Darwin's letter to a student at Jena and discusses the anti-Christian aspect of Darwinism. Even if the "letter is a forgery...it does not affect the main point... that without a specific act of Creation that undermines Christianity...."

New York Evangelist, October 19, 1882, volume 53, no. 42, page 2, reprints a letter from Charles Darwin, June 5, 1879 , who answered a question from a young student at Jena, in whose study of Darwin's books had raised religious doubts. This letter, "if true, puts an end to the speculations about Mr. Darwin being a Christian" The letter shows that if Darwinism "can be harmonized with Christianity, Mr. Darwin was not able to do it."

New York Evangelist, November 9, 1882, volume 53, no. 45, page 4, Religious Position of Charles Darwin is another article related to the response to the Jena student but here is an attempt to analyze Darwin, coming to the conclusion that "Mr. Darwin may be regarded as in large degree the victim of his own pursuits." His opinions "even on scientific questions will be subject to new scrutiny, and his theories as to man will begin to fade."

The Independent, November 9, 1882, volume 34, no. 1771, pages 1, 2, contains an article by Prof. E.D. Morris who examines Darwin's religious philosophy drawing, in part, on the letter to the young student in Jena.

Friends' Intelligencer, December 9, 1882, volume 39, no. 43, page 684, reprints an article from The Student by Joseph Rhoads, Jr., in which the author is indebted to Darwin's study of earthworms.

The Century, A Popular Quarterly, January, 1883, volume 25, no. 3, pages 420-432; The Debt to Science by Alfred R. Wallace. The title tells it all.

Littell's Living Age, February 3, 1883, volume 156, no. 2015, page 320, a report on Darwin's medical afflictions, reprinted from the British Medical Journal.

New York Evangelist, Feb 8, 1883, volume 54, no. 6, page 1, The Darwin's by J. Forsyth compares Grandfather Erasmus to Grandson Charles in terms of religious belief and uses Charles' letter to the Jena student as proof that he was not a Christian.

Zion's Herald, June 31, 1883, volume 60, no 5, page 39, in which is mentioned in an article by Alfred E. Wallace in the Century about the "debt of Science to Darwin" in which is suggests that many misconceptions of Darwin will be modified

And so on. 